\title{
A Methodology for the Identification and Assessment of the Conditions for the Practice of Outdoor and Sport Tourism-Related Activities: The Case of Northern Portugal
}

\author{
Goretti Silva ${ }^{1, *} \mathbb{0}$, Alexandra Correia ${ }^{1}$, Susana Rachão ${ }^{1}$, Alcina Nunes ${ }^{2}$, Elvira Vieira ${ }^{1}$, Sónia Santos ${ }^{3}$, \\ Luís Soares ${ }^{1}$, Manuel Fonseca ${ }^{1}{ }^{\circledR}$, Fernanda A. Ferreira $\left.{ }^{4}{ }^{(}\right)$, Cláudia Miranda Veloso ${ }^{5}{ }^{1}$, Paulo Carrança ${ }^{6}$ \\ and Paula Odete Fernandes ${ }^{2, * \mathbb{B}}$
}

check for updates

Citation: Silva, G.; Correia, A.;

Rachão, S.; Nunes, A.; Vieira, E.; Santos, S.; Soares, L.; Fonseca, M.; Ferreira, F.A.; Veloso, C.M.; et al. A Methodology for the Identification and Assessment of the Conditions for the Practice of Outdoor and Sport Tourism-Related Activities: The Case of Northern Portugal. Sustainability 2021, 13, 7343. https://doi.org/ $10.3390 /$ su13137343

Academic Editors: Célia M.Q. Ramos and Cláudia Ribeiro De Almeida

Received: 31 May 2021

Accepted: 23 June 2021

Published: 30 June 2021

Publisher's Note: MDPI stays neutral with regard to jurisdictional claims in published maps and institutional affiliations.

Copyright: (c) 2021 by the authors. Licensee MDPI, Basel, Switzerland. This article is an open access article distributed under the terms and conditions of the Creative Commons Attribution (CC BY) license (https:// creativecommons.org/licenses/by/ $4.0 /)$.
1 Escola Superior de Tecnologia e Gestão, Polytechnic Institute of Viana do Castelo, 4900-347 Viana do Castelo, Portugal; acorreia@estg.ipvc.pt (A.C.); susanarachao@estg.ipvc.pt (S.R.); evieira@esce.ipvc.pt (E.V.); luisandreferreirasoares@gmail.com (L.S.); manuelfonseca@esce.ipvc.pt (M.F.)

2 Instituto Politécnico de Bragança, UNIAG, 5300-253 Bragança, Portugal; alcina@ipb.pt

3 Escola Superior Agrária de Ponte de Lima, Polytechnic Institute of Viana do Castelo, 4900-347 Viana do Castelo, Portugal; ssantos@esa.ipvc.pt

4 Polytechnic Institute of Porto, UNIAG, 4200-465 Porto, Portugal; faf@esht.ipp.pt

5 School of Technology and Management (Águeda), University of Aveiro, GOVCOPP, R. Cmte. Pinho e Freitas 5, 3750-127 Águeda, Portugal; cmv@ua.pt

6 Turismo do Porto e Norte de Portugal, Polytechnic Institute of Viana do Castelo, 4900-347 Viana do Castelo, Portugal; paulo.carranca@portoenorte.pt

* Correspondence: goretti@estg.ipvc.pt or pof@ipb.pt

\begin{abstract}
Tourists' demand for outdoor sport-related activities has been growing in the last decade, leading to the recognition of the outdoor tourism potential of the development of rural and urban areas where the activities could take place. While the literature has recognized this potential, its features and the existing conditions for its practice are often not fully comprehended, mainly due to the lack of measurement systems and performance indicators. This study addresses this gap by proposing a wide-ranging assessment matrix of nine outdoor-related activities, employing northern Portugal as a study area. Based on an exploratory qualitative analysis employing semi-structured interviews with key stakeholders (public, private and third sector), the main contribution of this study lies in the development of the outdoor tourism assessment matrix (OTAM) to collect data. The OTAM matrix aims to identify and assess the conditions, namely the infrastructure and resources, for the practice of outdoor and sport tourism-related activities within the sustainable development pillars. The nine matrices comprising the OTAM allow the identification of the places where the outdoor activities can be practiced, and the conditions under which they can contribute to the definition of the development strategies of outdoor tourism.
\end{abstract}

Keywords: outdoor sport-related activities; outdoor tourism; assessment matrix; sports tourism; strategic planning

\section{Introduction}

Tourism in Portugal has been critical for the national economy, and the results obtained in the last year confirm the growth trend, reinforcing the importance of the sector [1]. In this context, outdoor tourism and sport-related outdoor activities play a decisive role in projecting local identities, underpinning the economic development of many regions [2], particularly in the context of natural and protected areas.

Outdoor tourism refers to a set of activities aimed at transforming leisure into dynamic, participatory and creative activities, making it possible to reconcile tourism, sports and nature, and allowing tourists to enjoy their activities in the richness of the environment [2]. As described by the Ministério da Economia [3], 'open-air tourism activities' are 
also known as 'outdoor activities', 'active tourism' or 'adventure tourism'. They refer to activities that, cumulatively: (i) predominantly take place in natural spaces, resulting in diversified experiences of enjoyment, experimentation and the discovery of nature and landscape, in physically equipped facilities or not; (ii) assume logistical organization and or supervision by the provider; (iii) imply a physical interaction of the recipients with their surroundings. In turn, 'cultural tourism activities' refer to pedestrian or transport activities, which promote contact with cultural and natural heritage through mediation between the recipient of the service and the cultural good being enjoyed, for knowledge sharing.

The aforementioned activities imply physical effort, to a greater or lesser extent, ranging from passive (e.g., sitting, relaxing, enjoying a view) to more active (e.g., skiing, mountain biking, horse riding), and they can be undertaken by individuals alone or in groups of family and friends [4]. When the focus is rather on an adventure, it also involves challenge and risk-taking [5]. Based on Beedie and Hudson [6], these activities can be distinguished into 'hard' and 'soft'. Activities like rafting, scuba diving, mountain biking, rappelling, cliff jumping, river crossing, paragliding, rock climbing and bouldering can be considered 'hard', whereas 'soft' outdoor activities include walking, cycling, camping, hiking, biking, animal watching, horseback riding, canoeing and water skiing [6]. In recent years, these activities have become increasingly important for the visited regions, given their economic implications, and therefore different forms of tourism have grown in popularity, and have captured practitioners' interest [4].

The outdoor nature-based tourist desires to participate in tours that provide discovery, learning, relaxation and escape from the routine of everyday life [7]. These activities can constitute a relevant economic alternative and a pillar for sustainable tourism, as they emphasize the need to value and preserve environmental ecosystems. This recognition creates opportunities to extend the existing knowledge about outdoor tourism activities from a supply perspective [8]. The effective planning and promotion of outdoor and sport tourism-related activities can only be accomplished after the identification and evaluation of natural and physical resources, and the conditions for their practice.

On the other hand, as outdoor and sport tourism-related activities grow, particularly in natural areas, the sites where they take place will experience increasing pressure. Moreover, because the quality of the destination's attributes exerts a significant influence over tourists' experiences, destination managing organizations (DMOs) are also increasingly interested in understanding how to sustainably develop outdoor sites, and how to ensure a good match between the expectations and experiences of tourists.

Despite some of the contributions found in the literature [9,10], the identification and assessment of the conditions for the practice of outdoor tourism activities have attracted relatively little attention, perhaps because of their complexity. Indeed, the evaluation research has tended to focus on issues such as human resources and budget, rather than concerns with outdoor facilities and conditions for the practice of the various activities. Additionally, most studies about outdoor tourism in nature sites focus mainly on the demand perspective, and not on supply, given the important role that the tourists' perception and satisfaction with the quality of the experiences plays in determining the destinations' images and market preferences [11].

However, the development of a formal system of the evaluation and classification of tourist sites is also of great relevance and has merit in the positioning and development of tourist destinations for several other reasons. First, the evaluation and classification of outdoor sites provide an opportunity for tourists to become aware of the destination and the importance placed on sustainable development. Second, outdoor nature sites involve attractive scenic landscapes that typically include the local community, roads and trails, and depend, more than other forms of tourism, on the quality of the environmental resources [12]. If tourists have access to an evaluation and rating for each of the elements found in these areas, they can better evaluate the sites and anticipate what can be expected. Third, there is a strong argument in favour of relating the price levels (entrance fees and permission from tour operators) directly to the level of experience found [13]. This 
indicates that the higher the satisfaction expected, the higher the price that may be charged, which favours the upsurge of complementary businesses, e.g., facilities for visitors. Such a development can increase the budget for nature conservation and motivate the participation and the benefit of local communities, contributing to the sustainability of tourist sites [14]

The present study aims to contribute to the filling of this gap in the literature through the construction of a comprehensive matrix that allows the assessment of the conditions and resources for the practice of outdoor and sport tourism-related activities within a framework of sustainable tourism development. To test the accuracy of the comprehensive matrix, northern Portugal was used as a study area, given its natural conditions for outdoor activities. Following this introduction, a literature review is reported, providing the rationale and theoretical framework underlying the proposed methodology. In Section 3, information on the data source and methodology is provided. Section 4 presents and discusses the results and, finally, Section 5 concludes.

\section{Literature Review}

There has been an increasing recognition of the positive benefits of practicing outdoor activities and tourism based on nature. Visiting natural environments and being outdoor are factors that are widely recognized as being important for the improvement of the health and wellbeing of citizens, enhancing social connections, connecting people with their natural and cultural heritage, generating revenue for use in conservation, contributing to local and regional economies, promoting local or indigenous identity, and developing conservation awareness [15-17]. These benefits exemplify the contributions of nature-based experiences to individual, community and social resilience and sustainability [18]. In this sense, when addressing the issue of sustainability, many advocate the 'quadruple bottom line', which refers to the environment, society, economy and governance [19].

Following this thinking, in September 2015, the General Assembly adopted the 2030 Agenda for Sustainable Development, which includes 17 Sustainable Development Goals (SDGs); building on the principle of "leaving no one behind", the new Agenda emphasises a holistic approach to reaching sustainable development for all [20]. The same source reinforces that the 17 SDGs are related to poverty, inequality, climate change, environmental degradation, peace and justice. Among the 17 objectives, three of them are particularly interconnected with the main objective of the present research. Namely, these are: SDG 13 , aiming at ensuring healthy lives and the promotion of well-being for all at all ages; SDG 10, stressing the need to reduce inequality within and among countries; and SDG 15, focusing on sustainably managed forests, combatting desertification, halting and reversing land degradation, and halting biodiversity loss [20]. Regarding SDG 3, it has been evident that the practice of physical exercise is associated with the well-being of citizens. This association is particularly relevant if exercises are practiced outdoors, contributing to the prevention of some diseases that will be contracted more quickly when a citizen's organism is more fragile. Another aspect that is of particular significance to this research is related to SDG 10. It is related to universal mobility. Keeping in mind the reduction of inequalities and ensuring that no one is left behind, the proposed assessment matrix includes the assessment of adaptive conditions concerning resources and infrastructures for the practice of outdoor and sport tourism-related activities for children and adults with disabilities.

In addition to the connection with the aforementioned SDGs, the focus of this work is particularly aligned with SDG 15 . The success of outdoor tourism lies mostly in high environmental quality and the conservation of environmental resources. Therefore, the concern of the assessment of the conditions and the appropriate infrastructure and equipment for outdoor activities lies within the higher need for a balance of biodiversity and the ecosystem, avoiding the degradation and damage of nature.

As such, the existence of an assessment matrix that enables us to assess areas where tourism is developing is not only vital to increase the appeal of outdoor tourism based in nature, rural and urban areas but also to guarantee its sustainable development. Moreover, poorly planned infrastructure stops future generations from benefiting from the resources, 
and damage to these resources has economic costs for society [21]. This also leads to failure in meeting tourist demands and a loss of opportunity for the future of tourism in these areas, as tourists prefer developed infrastructure [22,23]. Tourism planners should take the issues of infrastructure and safety assessment seriously as conditions for the longterm ecological, social and economic sustainability of tourism [24]. Besides this, specific destination attributes related to outdoor activities may function as tourism attractiveness factors [25]. Outdoor activities are undertaken on a range of public land tenures such as protected areas, i.e., designated mountain, rural, and natural areas, and the assessment of the existing conditions is of vital relevance. Many studies and methods exist for the identification and evaluation of the site and resource suitability for nature-based tourism, or ecotourism [26].

It is widely assumed that assessment matrices are a crucial tool to analyse the natural and physical conditions of a particular geographical region, particularly when it comes to natural environments with a high potential to attract tourism flows [27]. Therefore, each outdoor spot must be critically examined in light of different attributes to determine its overall conditions and its prospects for the sustainable practice of outdoor tourism activities. Because assessment matrices should be a comprehensive tool, their construction must rely on multi-method steps in order to ensure quantitative and objective outcomes [28]. The management of natural resources must include, as an important objective, their protection and preservation to guarantee their sustainability and the quality of the tourists' experiences.

However, most approaches have a partial perspective or focus on specific activities [22,29,30], protected areas [31], ecosystem services and landscapes attributes [32,33], or conflicting issues, as is the case of multiuse trails [34]. In his seminal contribution, Leopold [35] developed 46 criteria to describe landscape attributes. Cocklin et al. [36] developed an activity-based resource assessment technique by combining tax value and landscape value for recreation and tourism in New Zealand. Priskin's [37] study covered a regional resource assessment framework for nature-based tourism; elements of tourism infrastructure, accessibility assessment and landscape assessment; and a classification of natural resources. On the other hand, [24] suggested five types of environmental indicators and a checklist (1-the biodiversity and fragility of the ecosystem, 2-waste disposal, 3-water consumption, 4-the physical impact and intensity of the land use, and 5-visual effects, noise level and the protection of the atmosphere).

The methods often include qualitative approaches using checklists and expert opinions [22,37]. The checklists can vary, but often include the categories of attraction levels, infrastructure support, environmental destruction level and accessibility. Although some of these aspects are quite subjective or intangible, their suitability is assessed through a numerical rating system, including Likert-type scales varying from 1 to 5 , and 1 to 10 , and different labels (as too much/too little; very favourable/very unfavourable). A few studies have used objective measures. There are some exceptions though, as is the case of Troped et al. [29], who focused on testing/validating an audit tool to assess the characteristics of pedestrian and cycling environments. Safety issues and how these are perceived by consumers are also often referred to as concerns for outdoor activities [38].

Outdoor and sport tourism-related experiences are spatially-conditioned processes; therefore, the use of spatially oriented systems to assist sustainable tourism planning and management in existing destinations is needed [39]. Geographic information systems (GIS) are fundamental tools in tourism planning processes, both from a demand and supply-side perspective, with a special focus on resource inventory and strengthening the safeguarding of environmental resources. Moreover, enabling the monitoring of tourism activities also allows the detection of conflicting demands, and provides consumers with information about tourism destinations on the internet using map-based applications [40,41]. Additionally, GIS may help us to understand tourism behaviour through tourist time-space analysis. Overall, GIS systems contribute to raising the awareness of the importance of community involvement and participation in tourism development, as well as the stimulation and mod- 
elling of the spatial outcomes of different related topics [40,41]. Therefore, a comprehensive database that includes not only the amount but also the location of available outdoor recreational areas, as well as qualitative descriptions of services and other information is needed. This information can be used to assess the supply data and produce quality criteria and indicators for outdoor and sport tourism-related policies [26,42]. It may also facilitate the integration of planning regarding tourism [43], to access the impact on the environment resulting from tourism pressures [44], to implement a policy of the socially sustainable use of natural resources [22], and to assist stakeholders' decision-making in achieving sustainable tourism development [45].

Based on the aforementioned issues, a methodology was developed for outdoor and sport tourism-related activities used for the assessment of nature sites and resources' suitability for tourism development, culminating in an Outdoor Tourism Assessment Matrix (OTAM). Then, the OTAM was used and tested to assess all outdoor and sport tourism-related activities in northern Portugal, a process that is still undergoing, the results of which are out of the scope of this paper.

\section{Materials and Methods}

\subsection{Development of a Matrix as an Audit Tool for Outdoor and Sports Tourism-Related Activities}

The development of a matrix as an audit tool for the assessment of the resources and conditions for the practice of outdoor and sport tourism-related activities resulted from a combination of steps and methods implemented by a multidisciplinary research team (academics, tourism recreation professionals, sports professionals and public institutions). First came the identification and inventory of the different activities to be considered, and the analysis of how these would be organized, whether independently or grouped into sets of activities. The sets were proposed according to the perceived similarities regarding the aspects considered as relevant when assessing the conditions for outdoor and sports tourism-related activities. Based on this list (activities and/or sets of activities), the attributes to be considered within the assessment process of the spots in the northern region was then identified.

The second step was to go through the literature, most of which is referred to above, in the theoretical framework, as there was no example that was considered to fit the goals of this research. The identified attributes included, for example, the attraction levels of nature tourism-based resources [46,47], accessibility, the facilities available in place, the quality of the infrastructure [22,37], and physical attributes [8].

The third step of the research consisted of the analysis of international strategic documents, both from a broader perspective, as is the case of Sustainable Tourism in Protected Areas, and from a more specific perspective, such as the recommendations for the context of each activity, for example, 'Accessible' and 'Blue Flag Beaches' (European standards) in the case of surfing activities. This analysis enabled us to identify the attributes that had already been adopted and made available by federations and specific sports associations, and other organizations that care for the assurance of the quality and safety conditions within sports. In addition, relevant stakeholders, cases studies and examples were also identified through participation in specific events where online and relevant platforms were presented (e.g., All-in-Nature).

The fourth step of the research included exploratory semi-structured interviews conducted with key stakeholders in outdoor and sports tourism-related activities, as shown in Figure 1. More specifically, 15 semi-structured interviews were applied to adventure tourism businesses, nature-based tourism businesses, nautical tourism businesses, municipalities, local development associations, and the Nature and Forest Conservation Institute (ICNF) (Table 1). The technical interview (Table 2) structuring requirements were met, as the semi-structured interviews and were organized around a set of predetermined open questions, with other questions emerging from the dialogue between the interviewer and interviewee (always in accordance with the intended research objectives). Semi-structured exploratory interviews are the most commonly used interview format for qualitative 
research; in the present context, they were conducted once for each individual, lasting approximately $30 \mathrm{~min}$.

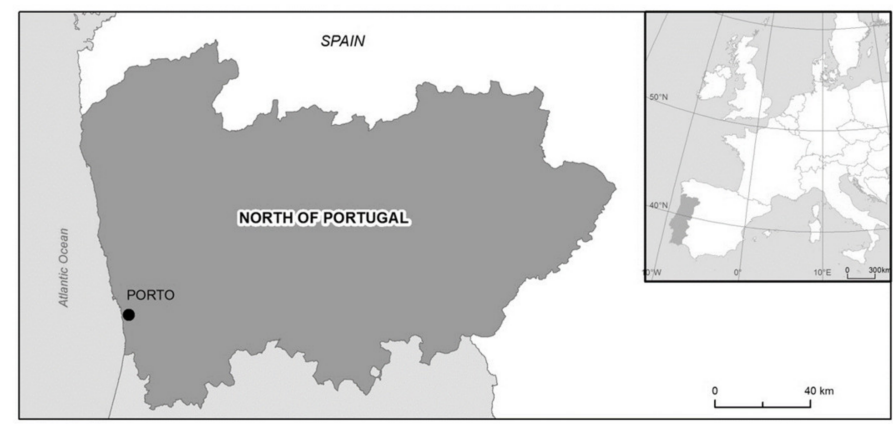

Figure 1. Northern Portugal. (Source: the authors.)

Table 1. Methodological process of the creation of the OTAM.

\begin{tabular}{|c|c|c|}
\hline $\begin{array}{l}\text { Process Step } \\
\quad \text { (Order) }\end{array}$ & The Goal of the Step in the Matrix Creation & Overall Contribution to the Development of the Matrix \\
\hline 1 st & $\begin{array}{l}\text { Conceptualisation of the outdoor tourism } \\
\text { and sport tourism-related activities }\end{array}$ & $\begin{array}{l}\text { To identify and organize the different activities to be } \\
\text { considered. }\end{array}$ \\
\hline 2nd & Conceptualisation of attributes measures & $\begin{array}{c}\text { To identify the attributes range, e.g., accessibility, facilities } \\
\text { available in place, and level of quality of infrastructure ( ... ). }\end{array}$ \\
\hline $3 r d$ & $\begin{array}{l}\text { Conceptualisation of international strategic } \\
\text { related documents }\end{array}$ & $\begin{array}{l}\text { To identify and to determine sustainable tourism practices in } \\
\text { protected areas, and recommendations for the context of each } \\
\text { outdoor activity. }\end{array}$ \\
\hline 4th & Consolidation and validation of the matrices & $\begin{array}{l}\text { To provide an evaluation based on expert knowledge and to } \\
\text { establish a consensus among outdoor tourism and sports' } \\
\text { experts. }\end{array}$ \\
\hline 5 th & $\begin{array}{l}\text { Selection of attributes from georeferencing } \\
\text { tools }\end{array}$ & $\begin{array}{l}\text { To identify the attributes and related assessment aspects being } \\
\text { used by international organizations, but also to understand } \\
\text { how they were being georeferenced. }\end{array}$ \\
\hline
\end{tabular}

Table 2. Interviewees' profiles.

\begin{tabular}{ccc}
\hline Sector & Interviewee Code & Business Operation \\
\hline & P1 & Senior Consultant for the development of the European \\
& Charters for Sustainable Tourism \\
Public (P) & P3 & Regional Development representative \\
& P4 & Regional Development representative \\
& P5 & Nature and Forest Conservation Institute representative \\
& PR2 & Municipality representative \\
Private (Pr) & PR3 & Specialist in nature tourism (soft adventure) \\
& PR4 & Specialist in nature tourism (soft adventure) \\
& PR5 & Specialist in nature tourism (soft adventure) \\
& PR6 & Specialist in outdoor sports (hard adventure) \\
Third-sector (T) & Specialist in nature tourism (soft adventure) \\
& T2 & Specialist in nature tourism (soft adventure) \\
Academic experts (AE) & AE1 (SS) & European Network of Outdoor Sports (ENOS) \\
& AE2 (JP) & Surf club representative \\
& & Specialist in Geographic Information Systems (GIS) \\
\hline
\end{tabular}


These interviews were intended to obtain a more thorough understanding of the conditions (attributes) that bind the practice of different outdoor and sport tourism-related activities, allowing a typology classification according to their scope and specificities, along with the identification of relevant and suitable areas for the practice of these activities. Considering the purpose of the research (the identification of aspects and criteria for the assessment of the conditions for outdoor and sports-related activities), and following Priskin [37], facilities associated with tourism services (e.g., accommodation, restaurants) were not considered in this research because these tend to be located in settlements.

Next, both national and international georeferencing tools (Geographic Information Systems, GIS) were analysed, not only to identify the attributes and related assessment aspects being used but also to understand how they were being georeferenced. In particular, the following tools were analysed: SIGTUR (Tourism Geographic Information Systems of Portugal) (https: / / sigtur.turismodeportugal.pt/(access on 10 January 2020)), Zoomazores (http:/ / www.zoomazores.com/(access on 10 January 2020)), Wenature (http: / / wenature.setima.pt/(access on 10 January 2020)), Flora.On (http:/ / flora-on.pt(access on 10 January 2020)), Biodiversidade Ameazada-Galicia and northern Portugal (http: / / biodiversidade.eu/(access on 10 January 2020)), Inaturalist-Uma Comunidade Para Naturalistas (https: / / www.inaturalist.org/(access on 10 January 2020)), and GBIF (Global Biodiversity Information Facility) (https:/ / www.gbif.org/pt/(access on 10 January 2020)).

Finally, and based on the information that resulted from previously described steps, the methodology adopted involved the development of nine different matrices regarding different types of activities. The nine matrices included both common and specific attributes, enabling the evaluation and classification of the places, which will be designated as outdoor spots, and the conditions they offer for the practice of outdoor and sport tourism-related activities. The matrices were developed taking into account the future creation of a common and shared database, which will include all of the information collected about tourism resources, products and services.

An excel file-bringing together the activities and attributes, and the ways in which these would be rated (e.g., Likert type scales, yes/no, open answers)—was sent to the transdisciplinary team via e-mail, for them to indicate any possible changes, and for the final validation.

The methodology proposed in this paper is systematic, and is suitable to be repeated elsewhere, and the OTAM can be applied in different geographical areas where the identified activities take place. The matrices for the assessment of outdoor and sports-related activities will be presented and discussed next.

\subsection{Site}

The North is the region of mainland Portugal with the third largest area, with $21,285.86 \mathrm{~km}^{2}$, and with the largest number of mountainous systems, including Gerês, Larouco, Marão, Montemuro, Montesinho, Nogueira, Padrela, Peneda and Soajo. The mountainous system with the highest maximum altitude is Larouco, with $1527 \mathrm{~m}$. The northern region is also the region with the largest number of river basins. The largest watershed is the Douro $\left(18,550 \mathrm{~km}^{2}\right)$ and the smallest is the Minho $\left(809 \mathrm{~km}^{2}\right)$. The main rivers that flow in the region are the Douro, Cávado, Ave, Lima and Minho.

Portugal has a total of 25,578,864 hectares (ha) of territory classified as Protected Areas, 251,947 ha of which are in the northern region, subdivided into natural parks, regional nature parks, national reserves, local nature reserves, and regionally protected landscapes. Of these protected areas, the Peneda-Gerês National Park (PNPG) is the only area classified as a national park in Portugal. The northern subregion with the largest area classified as protected is Trás-os-Montes, with 135,272 ha classified. The northern region also has a significant part of its territory classified under the Natura 2000 Network $(448,438$ ha) and the Ramsar Convention (346 ha). 
These features determine the northern region's diversity and uniqueness of natural resources, supporting the recognition of the existing potential for the development of outdoor and sport tourism-related activities. Among the well-established assets, the Portuguese Tourism Strategy 2027 identifies the sea, nature, biodiversity and inland waters-such as rivers, lakes and thermal waters-as key differentiating tourism destination assets [48]. Furthermore, this strategic plan highlights the valorisation of the territory by promoting the protection of its natural resources, and by addressing the importance of tourism to the maritime economy [49].

Northern Portugal is an area surrounded by mountains, rivers and the Atlantic Ocean. Its coastal area, ranging from Espinho to Caminha, covers several quality beaches and is attractive for water-based sports such as bodyboarding, surfing and kitesurfing due to the amount of national and international competitions throughout the year.

Regarding river-based experiences, activities such as canoeing, rafting and canyoning are practiced on the Minho and Paiva rivers, which have geological peculiarities that make them enablers of outdoor and sport tourism-related experiences [50].

According to Turismo de Portugal [51], the average stay remained the same for both foreigners ( 2.1 nights) and residents (1.5 nights), with the north being the region with the second most overnight stays from residents ( 3.2 million), increasing to 3.6\% between 2016 and 2017. The top five origins of tourists in the northern region (Spain, France, Brazil, Germany and the United Kingdom) represent $60 \%$ of foreigners in the region and a total of 2.5 million overnight stays. Also noteworthy are the growth of Brazil $(+31.7 \%)$ and the USA $(+31.1 \%)$. Tourism revenues in the northern region in 2017 amounted to $€ 430.3$ million, an increase of $18.9 \%$ compared to 2016, and the room occupancy in 2017 reached $64 \%$ and the bed occupancy reached $52.2 \%$, increasing by $3.3 \%$ and $2.1 \%$, respectively.

In spite of the above, it has also been acknowledged by academics and practitioners that there is the need for systematic knowledge of outdoor/nature-related supply and demand, i.e., the need for a more integrated and organized supply involving the different stakeholders, and the need for detailed geographic data (mapping of supply and demand). Among the well-established assets, the Portuguese Tourism Strategy 2027 identified the sea, nature, biodiversity, and inland waters, such as rivers, lakes and thermal waters, as key differentiating tourism destination assets [50].

\section{Results}

Based on the stages described above, the activities of relevance in northern Portugal were identified and, given their practical similarities, in a first broad perspective, were organized into two groups: (1) nautical sports, taking place in the coastal beaches, named as surfing activities; and (2) nature sports, taking place in natural, mountainous and rural areas. As such, nature sports (2), were then organized into sub-groups, according to similarities amongst them, particularly regarding the conditions required for them to be put into practice.

\section{List of Activities}

The outdoor sports/activities considered within this work were organized into the following groups and subgroups:

- Surfing activities (surfing, bodyboarding, stand up paddling, windsurfing, kitesurfing).

- Nature sports:
1. fishing;
2. cycling: BTT and downhill;
3. climbing;
4. rafting / canyoning;
5. paragliding and hang gliding;
6. wildlife watching. 
For all of these activities, attributes and ways of assessing the existing conditions concerning each of them were then identified. Some of the attributes are common to all of the activities, others are common to some activities, and a few are specific to each activity. The way of assessing/rating the existing conditions varies according to the type of each attribute but is always the same when that attribute is common to different activities.

\section{Outdoor and Sport Tourism-Related Activity Matrices}

Almost all nine matrices share common attributes, localization, the infrastructures and equipment that are available for carrying out the activities, the risks involved with its practice, associated entities/stakeholders, the ideal period to practice it, and the level of experience of the practitioners. As mentioned above, the information is collected using different types of questions requiring either non-structured (open) or structured (closed) answers. For instance, most of the localization attributes are of a single rating regarding the local geographical coordinates and protected areas; in the same way, the entities associated with each outdoor activity are identified, as well as the best period to visit the locality or practice the activity. The other attributes are classified considering a dichotomous answer or a multiple-choice with both a nominal scale and an ordinal scale. This type of classification is mainly used for attributes with a more specific character and is applicable to a few activities or even a single activity. Surfing activities have several attributes classified using these techniques, taking into account the importance of the weather and sea conditions for their practice.

Another way to classify attributes was based on a Likert-type scale, usually using five rating levels (in almost all of the activities, the response options for each attribute are the same). This kind of scale meets the need to limit the range of response options, especially from the stakeholders, thus allowing a more objective output. This technique was applied mainly to the issues regarding accessibility, infrastructure and equipment, local information or signage, security perception, and practitioners' levels of experience.

Figure 2 presents all of the attributes used for the classification of the various outdoor activities considered, as well as the type of technique used to classify each one. This figure shows separately the attribute matrices of surfing activities and nature sports.

Taking the 'hiking matrix' as an example, Table 3 shows the classification of a hiking outdoor activity between Montaria in northern Portugal and Baiona in Galicia, held within the Arga mountain. Although most of the attributes use open answers, others have a numerical scale. Regarding signalling/orientation, the numerical rating goes from " $1-$ There is no signage" to " 5 -There is online information and top-guides about the route, directional signage for the starting point of the route, homologated signage for the route and georeferenced information for the entire route". The general numerical scales used were based on Likert scales and reflect a positive progression of the attribute. 


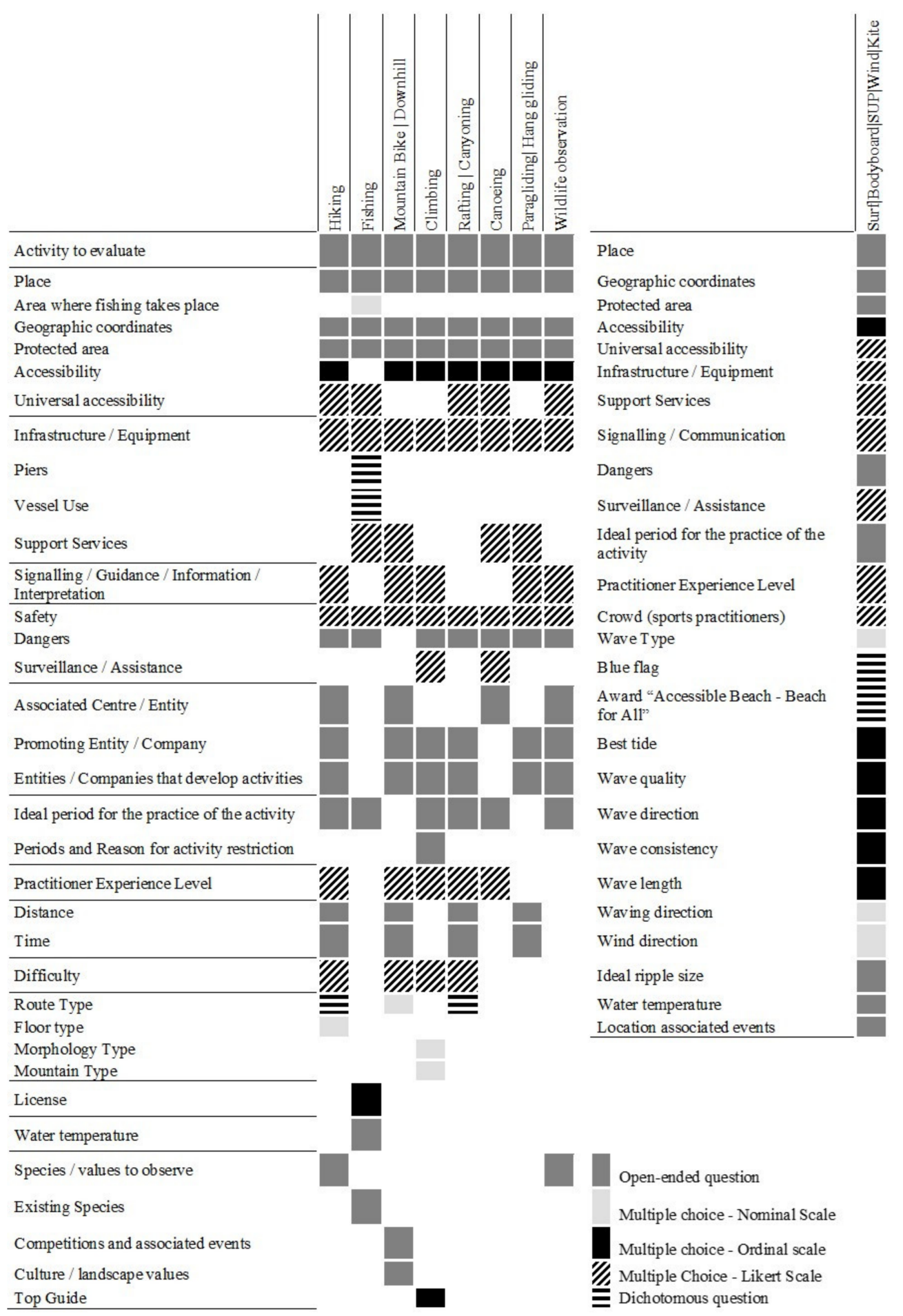

Figure 2. Outdoor activity matrices regarding outdoor nature sports and surfing activities. (Source: own elaboration.) 
Table 3. Hiking matrix example (Serra d'Arga hiking).

\begin{tabular}{|c|c|}
\hline & Hiking \\
\hline Activity to evaluate & $\begin{array}{c}\text { Viana do Castelo: Serra D'Arga, Vale do Lima e } \\
\text { Costa }\end{array}$ \\
\hline Place & Montaria-Baiona \\
\hline Geographic coordinates & - \\
\hline Protected area & Serra d'Arga \\
\hline Accessibility & 4 \\
\hline Universal accessibility & 3 \\
\hline Infrastructure/Equipment & Accommodation units/equipment rental \\
\hline Signalling/Guidance & 5 \\
\hline Information/Communication & 4 \\
\hline Safety & 5 \\
\hline Dangers & Falls \\
\hline Associated Interpretive Centre & No \\
\hline Promoting entity/company & AACS \\
\hline Entities/companies that develop activities & $\begin{array}{l}\text { Descubraminho; Follow the Camino; Camino } \\
\text { Aways; Tee travel; Portugal Green Walks. }\end{array}$ \\
\hline Ideal time to enjoy the place & February-June; September-November \\
\hline Practitioner Experience Level & 4 \\
\hline Distance & $240 \mathrm{~km}$ \\
\hline Time & 7 days $/ 6$ nights \\
\hline Difficulty & 2 \\
\hline Route Type & linear \\
\hline Floor type & mixed: road/pavement/clay/gravel \\
\hline Key values to observe & natural, heritage \\
\hline
\end{tabular}

Source: own elaboration.

Depending on the specific characteristics of each activity to be evaluated, the classification criteria may vary. By way of example, in hiking, the difficulty level assumes a range of five levels, ranging from " 1 -very easy (activity for all people, of short distance and duration, carried out on a regular and unpaved course, unevenness and of low physical intensity)" to "5-very difficult (activity with very long distances and durations performed on uneven floors and steep slopes at various stages of the course; requires good physical condition and regular exercise in high mountains and experience with climbing material". For mountain biking/downhill, the difficulty level is rated on a four-level scale that starts at "1-Easy" and ends at " 4 -Very hard", following the international classification standards.

As illustrated in Tables 4-8, the assessment matrices incorporate a wide range of different attributes that classify the resources. In terms of physically reaching the resources for the practice of the outdoor activities, accessibility and universal accessibility are classified on a scale ranging from 1 to 5 , stemming from the literature, e.g., [22,29,37,52].

The assessment matrix constructed (OTAM) within this research allows a systematic assessment of outdoor and sport tourism-related spots while contributing to the achievement of the universal 2030 Agenda for Sustainable Development and the Sustainable Development Goals (SDGs). 
Table 4. Accessibility suitability rating.

\begin{tabular}{|c|c|c|c|c|c|}
\hline \multirow[t]{2}{*}{ Attribute } & \multicolumn{5}{|c|}{ Attribute Suitability Rating } \\
\hline & 1 & 2 & 3 & 4 & 5 \\
\hline & Poor & Moderate to poor & Moderate & Moderate to good & Good \\
\hline Accessibility & On foot & $\begin{array}{c}\text { On foot, } \\
\text { non-motorized } \\
\text { vehicles and } \\
\text { two-wheel } \\
\text { motorized } \\
\text { vehicles; }\end{array}$ & $\begin{array}{c}\text { On foot, } \\
\text { non-motorized } \\
\text { vehicles, } \\
\text { motorized } \\
\text { two-wheeled } \\
\text { vehicles and light } \\
\text { motorized } \\
\text { four-wheeled } \\
\text { vehicles without } \\
\text { organized parking; }\end{array}$ & $\begin{array}{c}\text { On foot, } \\
\text { non-motorized } \\
\text { vehicles, motorized } \\
\text { two-wheeled vehicles, } \\
\text { light motorized } \\
\text { four-wheeled vehicles } \\
\text { with organized } \\
\text { parking, caravans, } \\
\text { motorhomes and } \\
\text { heavy vehicles with } \\
\text { organized parking; }\end{array}$ & $\begin{array}{l}\text { On foot, non-motorized } \\
\text { vehicles, motorized } \\
\text { two-wheeled vehicles, } \\
\text { light motorized } \\
\text { four-wheeled vehicles } \\
\text { with organized parking, } \\
\text { caravans, motorhomes, } \\
\text { heavy vehicles with } \\
\text { organized parking and } \\
\text { is served by public } \\
\text { transport networks. }\end{array}$ \\
\hline
\end{tabular}

Source: own elaboration.

Table 5. Signalling suitability rating.

\begin{tabular}{|c|c|c|c|c|c|}
\hline Attribute & & & Attribute Suitabi & y Rating & \\
\hline \multirow[b]{3}{*}{ Signalling } & 1 & 2 & 3 & 4 & 5 \\
\hline & Poor & Moderate to poor & Moderate & Moderate to good & Good \\
\hline & $\begin{array}{c}\text { There is no } \\
\text { signage }\end{array}$ & $\begin{array}{l}\text { There is online } \\
\text { information and } \\
\text { top guides on the } \\
\text { route }\end{array}$ & $\begin{array}{l}\text { There is online } \\
\text { information, top } \\
\text { guides and } \\
\text { directional signs } \\
\text { for the starting } \\
\text { point of the route }\end{array}$ & $\begin{array}{l}\text { There is online } \\
\text { information, top } \\
\text { guides, directional } \\
\text { signs and approved } \\
\text { signs for the route }\end{array}$ & $\begin{array}{l}\text { There is online } \\
\text { information, top guides, } \\
\text { directional signs, } \\
\text { approved signs and } \\
\text { georeferenced } \\
\text { information for the } \\
\text { entire route. }\end{array}$ \\
\hline
\end{tabular}

Source: own elaboration.

Table 6. Universal accessibility suitability rating.

\begin{tabular}{|c|c|c|c|c|c|}
\hline \multirow[t]{2}{*}{ Attribute } & \multicolumn{5}{|c|}{ Attribute Suitability Rating } \\
\hline & 1 & 2 & 3 & 4 & 5 \\
\hline & Poor & Moderate to poor & Moderate & Moderate to good & Good \\
\hline $\begin{array}{c}\text { Universal } \\
\text { Accessibility }\end{array}$ & $\begin{array}{l}\text { It is not } \\
\text { accessible to } \\
\text { people with } \\
\text { reduced mobility } \\
(\mathrm{RM})\end{array}$ & $\begin{array}{l}\text { Easy access, with } \\
\text { an accessible } \\
\text { route that allows } \\
\text { access to people } \\
\text { with RM }\end{array}$ & $\begin{array}{c}\text { Easy access, with } \\
\text { an accessible route } \\
\text { and space for } \\
\text { parking vehicles } \\
\text { for people with } \\
\text { RM }\end{array}$ & $\begin{array}{c}\text { Easy access, with } \\
\text { an accessible route, } \\
\text { parking of vehicles } \\
\text { and easy access to } \\
\text { support structures } \\
\text { for people with } \\
\text { RM }\end{array}$ & $\begin{array}{l}\text { Easy access, with an } \\
\text { accessible route, parking } \\
\text { of vehicles and easy } \\
\text { access to support } \\
\text { structures and } \\
\text { School/club/organisation } \\
\text { capable of providing } \\
\text { adapted service for } \\
\text { people with RM }\end{array}$ \\
\hline
\end{tabular}


Table 7. Information/communication suitability rating.

\begin{tabular}{|c|c|c|c|c|c|}
\hline Attribute & \multicolumn{5}{|c|}{ Attribute Suitability Rating } \\
\hline \multirow[b]{3}{*}{$\begin{array}{l}\text { Information/ } \\
\text { Communication }\end{array}$} & 1 & 2 & 3 & 4 & 5 \\
\hline & Poor & Moderate to poor & Moderate & Moderate to good & Good \\
\hline & $\begin{array}{l}\text { There is no } \\
\text { information }\end{array}$ & $\begin{array}{l}\text { There is online } \\
\text { information about } \\
\text { the route }\end{array}$ & $\begin{array}{l}\text { There is online } \\
\text { information and } \\
\text { informative panel } \\
\text { at the beginning of } \\
\text { the route }\end{array}$ & $\begin{array}{l}\text { There is online } \\
\text { information, } \\
\text { informative panel } \\
\text { at the beginning } \\
\text { and along the } \\
\text { route }\end{array}$ & $\begin{array}{l}\text { There is online } \\
\text { information, informative } \\
\text { panel at the beginning } \\
\text { and along the entire } \\
\text { route and associated } \\
\text { interpretive centre. }\end{array}$ \\
\hline
\end{tabular}

Source: own elaboration.

Table 8. Safety suitability rating.

\begin{tabular}{|c|c|c|c|c|c|}
\hline \multirow[t]{2}{*}{ Attribute } & \multicolumn{5}{|c|}{ Attribute Suitability Rating } \\
\hline & 1 & 2 & 3 & 4 & 5 \\
\hline & Poor & Moderate to poor & Moderate & Moderate to good & Good \\
\hline Safety & $\begin{array}{l}\text { There is no } \\
\text { type of } \\
\text { security } \\
\text { system } \\
\text { associated } \\
\text { with the } \\
\text { location }\end{array}$ & $\begin{array}{l}\text { There is an } \\
\text { information table } \\
\text { with emergency } \\
\text { numbers in the } \\
\text { place where the } \\
\text { activity starts }\end{array}$ & $\begin{array}{l}\text { There is an } \\
\text { information table } \\
\text { with emergency } \\
\text { numbers and with } \\
\text { the emergency } \\
\text { plan at the } \\
\text { beginning of the } \\
\text { place where the } \\
\text { activity starts }\end{array}$ & $\begin{array}{l}\text { There is an } \\
\text { information table } \\
\text { with emergency } \\
\text { numbers and a plan } \\
\text { at the beginning of } \\
\text { the place where the } \\
\text { activity starts and } \\
\text { along the entire } \\
\text { route }\end{array}$ & $\begin{array}{l}\text { There is an information } \\
\text { table with emergency } \\
\text { numbers and plan at the } \\
\text { beginning and along the } \\
\text { entire route. The entire } \\
\text { route is covered by a mobile } \\
\text { network for possible rescue } \\
\text { request by the practitioner. }\end{array}$ \\
\hline
\end{tabular}

Source: own elaboration.

\section{Discussion and Concluding Remarks}

This study aimed to develop a methodology for the identification and evaluation of outdoor spots' conditions for the practice of outdoor and sports tourism-related activities. The previous research emphasized the importance of assessing outdoor, nature and sports resources $[9,10]$. The proposed methodology addresses this research gap by suggesting a broad evaluation matrix, the OTAM, for various outdoor activities, and a set of attributes for each activity that are critical to the development and planning of outdoor and sports tourism-related resources. This allows the assessment of the characteristics, conditions and resources of rural and urban areas. The developed matrices also take into account the necessity and importance of georeferenced information [26,40-42], with the purposes of promoting systematic data collection in the field and the creation of a digital database that can be updated in the future.

The results obtained from the study area, i.e., northern Portugal, allowed the compilation of nine different matrices concerning the typology of different activities, namely hiking, fishing, mountain bike/downhill, climbing, rafting/canyoning, canoeing, paragliding/hang gliding and wildlife observation.

The present research findings underline that a comprehensive assessment of the resources can contribute to the sustainable development of the territory [22,43-45]. The nine matrices that constitute the OTAM allow the possibility of knowing clearly and easily where the identified outdoor spots/activities can be practiced and under which conditions, contributing to a broad knowledge in terms of the specified attributes. Thus, the proposed matrix has enormous value for planners, managers and decision-makers to know effectively the quality and quantity of resources, as well as their spatial distribution and their importance in terms of the sustainable development of the territory. By acknowledging the quality and quantity of resources through the employment of the OTAM, tourism planners can implement marketing and communication strategies promoting the practice 
of outdoor sports and wellbeing for the local communities and international tourism markets, in line with the SDG3.

Given the importance of an inclusive society in which all individuals are equals (SDG10), namely in the context of tourism and outdoor sports activities, the OTAM includes universal accessibility as one of the relevant attributes for the evaluation of each spot. With the systematic collection of data concerning accessibility, it will be possible to identify which places offer the conditions to be used by all people, regardless of any disability. Moreover, the outcomes derived from the overall OTAM can contribute to the identification of priorities in terms of conservation. The evaluation of the existing conditions as part of planning processes will enable the setting of rules and guidelines that will equally contribute to the preservation of natural resources (e.g., tourist carrying capacity), avoiding environmental and ecological degradation and contributing to SDG15. Additionally, in the planning and management of tourism destinations, the proposed tool can contribute to the definition of strategies aimed at the development and/or enhancement of outdoor and sport tourism. By having an overall knowledge about the conditions and the resources, decision-makers become better placed to make decisions about resource capability, land use compatibility and potential impacts. In this sense, the methodology proposed in this paper is systematic and the OTAM can be applied in the different geographical areas where the activities take place.

\section{Limitations and Future Research}

Nevertheless, some limitations of the study should be acknowledged. As the data collection regarding the fulfilment of the OTAM (e.g., climbing in northern Portugal) is still under process, the results and outcomes, and their discussion will be made available at a later date.

Thanks to the development of the OTAM, a web-based Geographical Information System will be created, which is capable of aiding the sustainable management of the tourism activity in the region, and is capable of serving as a tool to support the decisionmaking process and to support tourists' trip planning. For this reason, after completing the fulfilment of the OTAM in the geographical area to be implemented, future research could focus on the different outdoor and sport tourism-related activities taking place in northern Portugal and could assess the conditions in which outdoor spots provide quality tourism experiences.

Author Contributions: Investigation, G.S., A.C., S.R., A.N., E.V., S.S., L.S., M.F., F.A.F., C.M.V., P.C. and P.O.F. Methodology, G.S., A.C., S.R., A.N., F.A.F. and P.O.F. Project administration, P.O.F. (Principal Investigator) and A.C. (Co-Principal Investigator). Writing-original draft, S.R. and G.S., with the input of the different researchers involved in the project. All authors have read and agreed to the published version of the manuscript.

Funding: POCI-01-0145-ERDF-032289, financed by the European Investment Fund Regional Development (ERDF) through the Operational Program of Competitiveness and Innovation (POCI) and the Foundation for Science and Technology, I.P. (OE).

Institutional Review Board Statement: Not applicable.

Informed Consent Statement: Not applicable.

Data Availability Statement: Not applicable.

Acknowledgments: This project is being carried out within the scope of the TURNOUT ProjectDevelopment of Outdoor Tourism of Northern Portugal, POCI-01-0145-ERDF-032289, financed by the European Investment Fund Regional Development (ERDF) through the Operational Program of Competitiveness and Innovation (POCI) and the Foundation for Science and Technology, I.P. (OE). UNIAG, R\&D unit funded by the FCT-Portuguese Foundation for the Development of Science and Technology, Ministry of Science, Technology and Higher Education. "Project Code Reference: UIDB/04752/2020".

Conflicts of Interest: The authors declare no conflict of interest. 


\section{References}

1. Turismo de Portugal. Turismo em Portugal 2018. Travelbi Turismo de Portugal. Available online: https://travelbi. turismodeportugal.pt/pt-pt/Paginas/turismo-em-portugal-2018.aspx (accessed on 10 January 2020).

2. Leite, D.F.T. A Cultura Profissional dos Técnicos de Atividades de Animação Turística e de Turismo de ar Livre no Distrito de Coimbra. Master's Thesis, Polytechnic Institute of Coimbra, Coimbra, Portugal, 2018. (In Portuguese).

3. Ministério da Economia. Decreto-Lei no. 186/2015, de 3 de Setembro. Diário da República, 1.a Série, no. 172, $6947-6982.2015$. Available online: https:/ / dre.pt/application/conteudo/70179162 (accessed on 10 February 2020).

4. Bell, S.; Tyrvainen, L.; Sievanen, T.; Probstl, U.; Simpson, M. Outdoor recreation and nature tourism: A european perspective. Living Rev. Landsc. Res. 2007, 1, 1-46. [CrossRef]

5. Houge, M.S.; Kerr, J.H. Positive motivational experience over a three-day outdoor adventure trek in Peru. J. Adventure Educ. Outdoor Learn. 2017, 17, 4-17. [CrossRef]

6. Beedie, P.; Hudson, S. Emergence of mountain-based adventure tourism. Ann. Tour. Res. 2003, 30, 625-643. [CrossRef]

7. Mehmetoglu, M.; Normann, Ø. The link between travel motives and activities in nature-based tourism. Tour. Rev. 2013, 68, 3-13. [CrossRef]

8. Marzuki, A.; Hussin, A.A.; Mohamed, B.; Othman, A.G.; Som, A.P.M. Assessment of nature-based tourism in South Kelantan, Malaysia. Tourismos 2011, 6, 281-295.

9. Muñoz, L.; Hausner, V.; Brown, G.; Runge, C.; Fauchald, P. Identifying spatial overlap in the values of locals, domestic-and international tourists to protected areas. Tour. Manag. 2019, 71, 259-271. [CrossRef]

10. Marrosu, G.M.; Balvis, T. Environmental impact assessment in climbing activities: A new method to develop a sustainable tourism in geological and nature reserves. Geoheritage 2020, 12, 1-16. [CrossRef]

11. Cerdeiro, M. A Importância da Imagem na Definição de um Destino Como Turístico: Estudo de Caso Monte Real. Master's Thesis, Polytechnic Institute of Leiria, Leiria, Portugal, 2014. (In Portuguese).

12. Boyd, S.W.; Chard, R.; Butler, W. Managing ecotourism: An opportunity spectrum approach. Tour. Manag. 1996, 17, 557-566. [CrossRef]

13. Buckley, R.C. Ecological indicators of tourist impacts in parks. J. Ecotourism 2003, 2, 54-66. [CrossRef]

14. Carius, F.; Job, H. Community involvement and tourism revenue sharing as contributing factors to the UN sustainable development goals in jozani-chwaka bay national park and biosphere reserve, zanzibar. J. Sustain. Tour. 2019, 27, 826-846. [CrossRef]

15. Hartig, T.; Mitchell, R.; de Vries, S.; Frumkin, H. Nature and health. Annu. Rev. Public Health 2014, 36, 207-228. [CrossRef]

16. Frumkin, H.; Bratman, G.N.; Breslow, S.J.; Cochran, B.; Kahn, P.H., Jr.; Lawler, J.J.; Levin, P.S.; Tandon, P.S.; Varanasi, U.; Wolf, K.L.; et al. Nature contact and human health: A research agenda. Environ. Health Perspect. 2017, 125. [CrossRef]

17. Wolsko, C.; Lindberg, K.; Reese, R. Nature-based physical recreation leads to psychological well-being: Evidence from five studies. Ecopsychology 2019, 11, 222-235. [CrossRef]

18. Winter, P.L.; Padgett, P.E.; Milburn, L.S.; Li, W. Neighbourhood parks and recreationists' exposure to ozone: A comparison of disadvantaged and affluent communities in Los Angeles, California. Environ. Manag. 2019, 63, 379-395. [CrossRef]

19. Alibašić, H. Sustainability and Resilience Planning for Local Governments: The Quadruple Bottom Line Strategy; Springer International Publishing: Cham, Switzerland, 2018; pp. 1-120.

20. United Nations. About the Sustainable Development Goals. 2019. Available online: https://www.un.org/sustainabledevelopment/ sustainable-development-goals (accessed on 23 May 2020).

21. Ayoo, C. Community-based natural resource management in Kenya. Manag. Environ. Qual. An Int. J. 2007, 18, 531-541. [CrossRef]

22. Alaeddinoglu, F.; Can, A.S. Identification and classification of nature-based tourism resources: Western lake van basin, turkey. Procedia-Soc. Behav. Sci. 2011, 19, 198-207. [CrossRef]

23. Hearne, R.R.; Salinas, Z.M. The use of choice experiments in the analysis of tourist preferences for ecotourism development in costa rica. J. Environ. Manag. 2002, 65, 153-163. [CrossRef]

24. Lim, C.; McAleer, M. Ecologically sustainable tourism management. Environ. Model. Softw. 2005, 20, 1431-1438. [CrossRef]

25. Lee, C.F. Understanding the factors determining the attractiveness of camping tourism: A hierarchical approach. Tour. Plan. Dev. 2020, 17, 556-572. [CrossRef]

26. Bunruamkaewa, K.; Murayamaa, Y. Site suitability evaluation for ecotourism using GIS \& AHP: A case study of Surat Thani Province, Thailand. Procedia-Soc. Behav. Sci. 2011, 21, 269-278.

27. Doan, T.M. Sustainable ecotourism in Amazonia: Evaluation of six sites in Southeastern Peru. Int. J. Tour. Res. 2013, 15, $261-271$. [CrossRef]

28. Xiang, C.; Xiao Qin, J.; Yin, L. Study on the rural ecotourism resource evaluation system. Environ. Technol. Inno. 2020, 20. [CrossRef]

29. Troped, P.J.; Cromley, E.K.; Fragala, M.S. Development and reliability and validity testing of an audit tool for trail/path characteristics: The path environment audit tool (PEAT). J. Phys. Activ. Health 2006, 3, 158-175. [CrossRef] [PubMed]

30. Xu, S.; Leung, Y.F.; Barbieri, C. Characterizing themed touring routes: A geospatial and tourism evaluation of wine trails. Tour. Plan. Dev. 2016, 13, 168-184. [CrossRef]

31. Deng, J.; King, B.; Baur, T. Evaluating natural attractions for tourism. Ann. Tour. Res. 2002, 29, 422-438. [CrossRef] 
32. Martin, S.A.; Assenov, I. Investigating the importance of surf resource sustainability indicators: Stakeholder perspectives for surf tourism planning and development. Tour. Plan. Dev. 2014, 11, 127-148. [CrossRef]

33. Hermes, J.; Van Berkel, D.; Burkhard, B.; Plieninger, T.; Fagerholm, N.; von Haaren, C.; Albert, C. Assessment and valuation of recreational ecosystem services of landscapes. Ecosyst. Serv. 2018, 31, 289-295. [CrossRef]

34. Beeton, S. Sustainable tourism in practice: Trails and tourism, critical management issues of multi-use trails. Tour. Hosp. Plan. Dev. 2006, 3, 47-64. [CrossRef]

35. Leopold, L.B. Quantitative Comparisons of Some Aesthetic Factors Among Rivers; Report No. Survey Circular 620; U.S. Government Printing Office: Washington, DC, USA, 1969.

36. Cocklin, C.; Harte, M.; Hay, J. Resource assessment for recreation and tourism: A new zealand example. Landsc. Urban Plan. 1990, 19, 291-303. [CrossRef]

37. Priskin, J. Assessment of natural resources for nature-based tourism: The case of the Central coast region of western Australia. Tour. Manag. 2001, 22, 637-648. [CrossRef]

38. Pickering, C.; Castley, J.G.; Hill, W.; Newsome, D. Environmental, safety and management issues of unauthorised trail technical features for mountain bicycling. Landsc. Urban Plan. 2010, 97, 58-67. [CrossRef]

39. Beeco, J.A.; Brown, G. Integrating space, spatial tools, and spatial analysis into the human dimensions of parks and outdoor recreation. Appl. Geog. 2013, 38, 76-85. [CrossRef]

40. Jovanovic, V.; Njegus, A. The application of GIS and its components in tourism. Yugosl. J. Oper. Res. 2008, 18, 261-272. [CrossRef]

41. Ruda, A. Exploring tourism possibilities using GIS-based spatial association methods. Geog. Tech. 2016, 11, 87-101. [CrossRef]

42. Petersson-Forsberg, L. Swedish spatial planning: A blunt instrument for the protection of outdoor recreation. J. Outdoor Recreat. Tour. 2014, 5, 37-47. [CrossRef]

43. De Valck, J.; Landuyt, D.; Broekx, S.; Liekens, I.; De Nocker, L.; Vranken, L. Outdoor recreation in various landscapes: Which site characteristics really matter? Land Use Policy 2017, 65, 186-197. [CrossRef]

44. Schroeder, S.A.; Fulton, D.C.; Cornicelli, L.; McInenly, L.E. Recreation conflict, coping, and satisfaction: Minnesota grouse hunters' conflicts and coping response related to all-terrain vehicle users, hikers, and other hunters. J. Outdoor Recreat Tour. 2020, 30. [CrossRef]

45. Schägner, J.P.; Brander, L.; Paracchini, M.L.; Maes, J.; Gollnow, F.; Bertzky, B. Spatial dimensions of recreational ecosystem service values: A review of meta-analyses and a combination of meta-analytic value-transfer and GIS. Ecosyst. Serv. 2018, 31, 395-409. [CrossRef]

46. Clius, M.; Patroescu, M. An evaluation matrix for ecotourism potential in certain categories of protected areas in Romania. Case studies: National park, Nature Park, Geopark. In Proceedings of the 14th International Multidisciplinary Scientific Geoconference and EXPO, Albena, Bulgaria, 17-26 June 2014; pp. 9-16. [CrossRef]

47. Silveira, C. Açores, Um Destino Cultural e Paisagístico Sustentável. Master Thesis, Estoril Higher Institute for Tourism and Hotel Studies, Estoril, Portugal, 2011. (In Portuguese).

48. Araújo, L. Portuguese tourism strategy 2027: Leading the tourism of the future. Worldw. Hosp. Tour. Themes 2017, 9, 646-652. [CrossRef]

49. Turismo de Portugal. Estratégia Turismo 2027. Available online: https:/ / estrategia.turismodeportugal.pt/sites / default/files / Estrategia_Turismo_Portugal_ET27.pdf (accessed on 10 January 2020).

50. Oliveira, C.P.D. Caracterização do mercado de actividades de Turismo de Natureza em Portugal. Master's Thesis, University Nova de Lisboa, Lisboa, Portugal, 2013. (In Portuguese).

51. Turismo de Portugal. Turismo em Portugal 2017. Travelbi Turismo de Portugal. Available online: https:/ / travelbi.turismodeportugal. pt/pt-pt/Documents/Turismo\%20em\%20Portugal/turismo-em-portugal-2017.pdf (accessed on 10 January 2020).

52. UN World Tourism Organization. Highlights of the 1st UNWTO Conference on Accessible Tourism in Europe (San Marino, 19-20 November 2014). Available online: https: / / www.e-unwto.org (accessed on 23 June 2021). 